\title{
The Value to Banks of Small Business Lending
}

\author{
Dmytro Holod and Joe Peek
}

\begin{abstract}
:
By estimating the market premium placed on the small business loan portfolios of banking organizations, this study provides direct evidence on the value to banks arising from relationship lending. Using data from the small business loan survey contained in the June bank call reports, we find that small commercial and industrial loans do, in fact, add value for smaller banking organizations, both in absolute terms and relative to the value contributed by larger commercial and industrial loans. Interestingly, the value-enhancing effect emanates primarily from the smallest loans, those with original values of $\$ 100,000$ or less. On the other hand, small commercial real estate loans, being transactional rather than relationship in nature, do not contribute additional value to banking organizations relative to larger commercial real estate loans.
\end{abstract}

\section{JEL Classifications: G21}

Dmytro Holod is an associate professor of finance and director of graduate studies at the College of Business at SUNY - Stony Brook. Joe Peek is a vice president and head of the financial group in the research department at the Federal Reserve Bank of Boston. Their e-mail addresses are dmytro.holod@sunysb.edu and joe.peek@bos.frb.org, respectively.

An earlier version of this study received financial support from the Office of Advocacy of the U.S. Small Business Administration.

This paper, which may be revised, is available on the web site of the Federal Reserve Bank of Boston at http://www.bostonfed.org/economic/wp/index.htm.

The statements, findings, conclusions, and recommendations found in this study are those of the authors and do not necessarily reflect the views of the Office of Advocacy, the United States Small Business Administration, the Federal Reserve Bank of Boston, or the Federal Reserve System.

This version: August 15, 2013 


\section{Introduction}

The development of long-term bank-firm relationships should provide benefits by reducing informational asymmetries, particularly when the borrowers are smaller, more opaque firms. Less clear, however, is how these benefits are allocated between the lenders and the borrowers. While small firms potentially can benefit from increased credit availability on better terms, relationship lenders potentially can exploit their informational monopoly over these firms by subjecting them to "hold-up" costs, whereby lenders extract the benefits for themselves by making loans on non-competitive terms to relationship borrowers. Although an extensive literature has established convincingly that borrowers accrue substantial benefits, little direct evidence exists about the value of lending relationships to lenders. Instead, studies that do focus on the benefits to lenders tend to provide only indirect evidence about the value-enhancing effects on the banks of lending relationships.

By estimating the market premium placed on the small business loan portfolios of banks, this study provides direct evidence that relationship lending enhances the value of banking organizations. ${ }^{1}$ Such a finding has important implications for bank behavior. For example, given the well-known inverse relationship between bank size and the portfolio share of small business loans, the ongoing consolidation in the banking industry will, with the consequent increase in bank size, tend to shrink the share of small business loans in the loan portfolio of the combined banking organization. This consolidation may be value destroying for the acquirer to the extent that value-enhancing small business lending by acquired banks with a particular expertise in small business lending may be de-emphasized as a result of the acquisition, and thus not be in the best interests of the acquirer's shareholders.

How might small business lending enhance bank value? First, relationship lending, unlike transactional lending, provides the bank with the opportunity to exploit the private information it acquires during the course of relationships (see, for example, Sharpe 1990; Rajan

1 Because the analysis requires stock market valuations, the unit of analysis is banking organization. For simplicity, we will refer in the text to banks or BHCs (bank holding companies), although the publicly traded banking organizations included encompass bank holding companies, financial services holding companies, and individual banks not in a holding company. 
1992; Stein 2002). ${ }^{2}$ Second, the bank can benefit from its opportunities to cross-sell additional products and services, such as relatively inexpensive core deposit services and investment banking services, to its relationship borrowers. Third, the value to banks from relationship borrowers reflects not only the profitability from current business with these customers, but also the profits that might accrue from future opportunities to continue and broaden the menu of offerings provided to these customer firms as the firms expand in terms of both size and scope of activities.

A relationship bank has an opportunity to earn rents from informationally captured firms by exploiting the proprietary (and superior) information acquired through long-term relationships by measuring more precisely the credit risk of these firms through repeated interactions. It does so by charging an interest rate that is higher than justified by the level of credit risk perceived by an informed lender, yet lower than the interest rate other potential lenders would charge to compensate for the added risk associated with having less information about the firm. Thus, the firm has an incentive to remain with the relationship bank rather than to defect and begin a new relationship with another lender. In any case, because it is costly and time consuming to establish new lending relationships, firms are subject to a lock-in effect with their current relationship lender. Consequently, the hold-up costs imposed on these relationship borrowers enhance bank profit.

At least partly offsetting these benefits for banks are the costly information collection and processing activities required for relationship-based finance. In particular, the advantage to the relationship bank arises from the opportunity to collect "soft" information, which is more difficult and more costly to verify, about smaller, relatively opaque firms, rather than the more widely available, less costly and easier to evaluate "hard" (quantifiable) information available to potential lenders about larger, more transparent firms. Given the expense associated with screening and monitoring small, opaque firms, the rents earned by a relationship bank could simply be compensation for its information production and monitoring efforts, and not really represent economic rents. However, if the rents earned from the bank's informational monopoly

2 Boot (2000) provides an informative overview of the issues associated with relationship lending by banks. 
power more than compensate the lender for the additional information costs incurred in screening and monitoring, then relationship loans would add value to a relationship bank.

However, even though relationship lending to small firms may have been profitable in the past, the increased competition among lenders in more recent years associated with bank consolidation and technological advances, including the increased use of credit scoring models by larger and/or more distant banks, may have sharply reduced the profitability of relationship lending. In fact, a number of studies have documented a rise in the use of credit scoring for small business lending even among small and mid-sized banks (for example, DeYoung, Glennon, and Nigro 2008; DeYoung et al. 2011; Berger, Cowen, and Frame 2011). Still, it can be argued (for example, DeYoung, Hunter, and Udell 2004) that a focus on relationship lending by well-managed community banks remains an economically viable strategy.

Using data from the small business loan survey contained in the June bank-level Consolidated Reports of Condition and Income (call reports), we estimate the relationship between the book and market values of bank small business loan portfolios to identify the contribution of lending relationships to the market value of banking organizations. We find that for commercial and industrial (CI) loans, small business lending does, in fact, add value to banking organizations both overall and relative to large CI loans, with the effect emanating primarily from small and mid-sized banking organizations, as would be expected. Furthermore, the effect comes primarily from the smallest category of small CI loans, those with original amounts of $\$ 100,000$ or less. On the other hand, small commercial real estate (CRE) loans, being transactional rather than relationship in nature, do not contribute additional value to banking organizations beyond that produced by CRE loans generally.

In what follows, Section II provides a brief discussion of relationship lending, emphasizing how and why relationship lending might add value to a banking organization and summarizing the literature that investigates the sources and magnitudes of any such value. Section III discusses the data used in the study. Section IV presents the specification of our empirical tests. Section V presents and discusses the empirical results. Section VI concludes. 


\section{Background}

Much of the literature on relationship lending has focused on asymmetric information problems associated with smaller firms that are informationally opaque as compared with large firms that are much more transparent. Small firms often have little or no collateral and, in many cases, are relatively young firms lacking an extensive history from which future performance can be extrapolated. Because of their small size and the absence of substantial public information about their quality, such firms have virtually no access to external funds from national markets, such as through the issuance of commercial paper, bonds, or publicly traded equity. Therefore, small firms tend to be dependent on banks for external funds. However, banks are not well informed about the credit risk associated with these informationally opaque firms when they receive an initial loan application. Therefore, the formation of bank-firm relationships requires investment by banks in acquiring and processing information, and in subsequently monitoring the activities of the firms to which they decide to lend.

Over time, the borrowing firm develops a private reputation with its lender, based on the accumulated payment history of the borrower and other information gleaned from bank monitoring activities. For example, a bank-firm relationship typically involves the bank providing various additional financial products and services to the borrowing firm. Such crossselling of financial products and services to relationship borrowers facilitates the information acquisition process of banks and strengthens the implicit long-term commitment to the relationships, in addition to enhancing bank revenues. For example, by monitoring business checking accounts, banks can gather timely data on a firm's cash inflows and outflows, payroll, and other major expenses, as well as on the performance of accounts receivables (Nakamura 1993; Mester, Nakamura, and Renault 1998). Thus, transactions accounts not only serve as inexpensive sources of funds for banks, they also provide banks with valuable information that is typically unavailable to other potential lenders. 
In contrast, much bank lending is transactional in nature. ${ }^{3}$ For example, many large banks, and some smaller banks, lend to small firms using credit scoring models, basing their loan decisions on quantifiable information rather than on private, more qualitative information acquired through direct interaction with the firm. ${ }^{4}$ Instead of making more subjective judgments based on direct interactions with a small firm, credit scoring applies statistical methods to quantifiable data, summarizing borrower characteristics to produce a score that can be used to evaluate the likelihood of repayment.

Even though credit scoring can be applied to many small firms, lending to large firms remains quite different than lending to small firms because large firms tend to be more established and lenders typically can evaluate more precisely the credit risk of the firm by using public information. Due to their relatively greater transparency, the largest firms typically have access to national debt and equity markets, and can borrow from multiple banks under less restrictive loan contract terms than small firms. Thus, financial statement lending to large, relatively transparent firms is unlikely to be a source of economic benefit from bank-firm relationships established to reduce information asymmetries. Similarly, other transactionsbased lending technologies, such as fixed-asset lending, are unlikely to benefit from bank-firm relationships based on private information, since the technology for valuing collateral is relatively straightforward. Rather, the benefits would tend to arise primarily from economies of scale. For example, commercial real estate lending, which is based on a hard-information technology (appraisal values), may provide large banks an economies-of-scale advantage over smaller banks (for example, Berger and Black 2011).

For the reasons outlined above, a bank can expect to receive greater value from an investment in forming and maintaining a relationship with a small firm than with a large, more transparent firm. And because large banks have greater potential to benefit from economies of scale in transactional lending, one might expect smaller banks to specialize in relationship

3 See Berger and Udell (2006) for a discussion that classifies bank lending technologies into relationship lending and five types of transactional lending: financial statement lending, asset-based lending, factoring, fixed-asset lending, and small business credit scoring.

4 A number of recent papers have investigated the use of credit scoring models, for example, Cole, Goldberg, and White (2004), Berger, Frame, and Miller (2005), DeYoung, Glennon, and Nigro (2005), DeYoung, Glennon, and Nigro (2008), DeYoung et al. (2011), and Berger, Cowen, and Frame (2011). 
lending, while larger, more complex banking organizations would tend to specialize in transactional lending. However, the proper distinction is not only bank size, but the organizational structure of the banking organization. For example, Stein (2002) argues that large hierarchies are better at processing hard information, while a decentralized structure is more conducive to using soft information, leaving the large hierarchical firms, which tend to suffer from organizational diseconomies, at a comparative disadvantage at processing soft information. Similarly, Berger and Udell (2002) emphasize the agency problems associated with hierarchal organizational structures, especially for dealing with the soft information upon which relationship lending is based. In general, the literature concludes that small banks may have an advantage over large banks in relationship lending (for example, Carter et al. 2004; DeYoung et al. 2004; Berger et al. 2005).

While the development of long-term bank-firm relationships certainly has the potential to provide benefits through the reduction in informational asymmetries associated with small, opaque firms, the allocation of those benefits between the lenders and borrowers is unclear. In fact, previous studies have established that long-term lending relationships between banks and firms are valuable to small firms in terms of increased credit availability and protection against adverse credit shocks (for example, Petersen and Rajan 1994; Berger and Udell 1995; Cole 1998). And, even for large firms, the announcement of an origination or the renewal of a major bank loan has been shown to be a positive signal to the stock market (for example, James 1987; James and Wier 1990). Similarly, the termination (or increased probability of termination) of lending relationships adversely affects the market value of a borrower (for example, Slovin, Shushka, and Polonchek 1993; Dahiya, Puri, and Saunders 2003).

On the other hand, relatively little direct evidence exists about the value of lending relationships to lenders. Instead, studies that do focus on the potential benefits to lenders tend to provide only indirect evidence on the value-enhancing effects of lending relationships on the banks. For example, even if lenders are able to exploit their informational advantage over relationship borrowers, it is not clear that the resulting hold-up revenues more than compensate for the costly information collection and monitoring required. Similarly, relationship lenders 
may share the benefits of cross-selling additional (current and future) products to relationship borrowers through discounted pricing.

In terms of future business opportunities, Bharath et al. (2007) find that relationship lenders are much more likely than non-relationship lenders to provide future loans to their borrowers. This is especially the case for smaller, unrated borrowers that suffer from greater informational asymmetry. In addition, relationship lenders have a much greater probability of being chosen as a lead underwriter for an initial public offering (IPO). Ljungqvist, Marsten, and Wilhelm, Jr. (2006) also find evidence that lending relationships contribute to commercial banks increasing their probability of obtaining a debt underwriting mandate from a firm. Similarly, Yasuda (2005) finds that bank relationships affect debt underwriter choice, especially for junkbond issuers and first-time issuers, firms for which bank-firm lending relationships are likely to be more important.

However, Yasuda (2005) also finds that the lending relationships are associated with lower underwriting fees, perhaps because the marginal cost of obtaining information about the firm is lower than for a non-relationship underwriter. Still, insofar as these underwriting discounts reduce the profitability of the future business activities that arise from maintaining lending relationships with firms, the value of such lending relationships to banks would be diminished. Similarly, while Bharath et al. (2007) find that past lending relationships increase the probability that a lender will obtain future lending and investment banking business from a firm, they also find that the costs charged to the firm for relationship loans and the fees charged for underwriting an IPO tend to be lower, not higher, than the costs charged other borrowers, suggesting that relationship banks do not fully exploit any monopoly power they may have over the firms. Although Bharath et al. (2007) do find that fees for debt underwriting are higher for relationship borrowers, it is not clear that the higher fees are associated with rent extraction rather than serving as compensation for obtaining more favorable terms for the firms' debt issues.

The most likely way that banks can earn monopoly rents from informationally captured relationship borrowers is by increasing loan rates as the duration of the relationship lengthens. However, because the cost of monitoring decreases as relationships progress over time, a lender 
still can capture some of the value created by relationships even if interest rates do not rise with the duration of the relationship. In fact, Petersen and Rajan (1994) find evidence consistent with banks capturing relationship value in this way. In contrast, Berger and Udell (1995) find that the interest rates charged decline as relationships progress, although the important point for value creation for lenders is whether interest rates decline faster than the declining costs of information collection and monitoring. While Bharath et al. (2011) also find that loan spreads tend to decline with repeated borrowing from the same lender, especially for the relatively opaque borrowers, their loan sample focuses on syndicated loans to publicly traded firms rather than on bank-dependent firms that would be more likely to be subject to rent extraction from informational capture.

In contrast, a number of studies have found evidence that lenders raise interest rates as relationships progress, consistent with lenders exploiting the lock-in effect from having an informational monopoly over relationship borrowers. For example, Degryse and Van Cayseele (2000) find that interest rates rise with the duration of bank-firm relationships, although this effect is moderated to the extent that the relationship exhibits greater scope in terms of the firm purchasing additional products from the lender.

Of course, before a lender can exploit the lock-in effect, it must entice the firm to begin a relationship with the bank. Sharpe (1990) and Rajan (1992) argue that banks may initially offer below-market rates to firms, relative to their perceived credit risk, and only later be compensated by higher interest rates as the relationship progresses. Ioannidou and Ongena (2010) find just such a pattern. When a firm switches to a new bank, the initial loan tends to have a substantially lower interest rate than the rates charged on comparable new loans to existing customers by both the firm's new bank and the firm's current banks. While the interest rate charged by the new bank tends to fall further during the first year of the relationship, perhaps to cement the relationship, the new bank soon begins to increase the interest rate so that the interest rate advantage from switching lenders evaporates and the firm is again exposed to hold-up costs. Moreover, this interest rate cycle is more pronounced for firms with greater potential to be exposed to hold-up costs, such as firms with greater informational asymmetries between existing lenders and potential new lenders. 
Santos and Winton (2008) provide additional evidence that hold-up costs are tied to the ability of lenders to opportunistically exploit their informational advantage. In particular, they find a business cycle effect whereby lenders raise loan interest rates more during recessions for bank-dependent borrowers than for firms with access to public bond markets. Consistent with the idea that firms with access to bond markets are less exploitable by banks, Santos and Winton (2008) show that the differential increase in bank loan interest rates that they find is due primarily to hold-up costs rather than to differences in the increase in borrower risk during recessions. Similarly, by comparing the interest rate spreads paid on loans by firms before and after the firms obtain access to public debt markets, Hale and Santos (2009) find direct evidence that firms having access to bond markets weakens the ability of bank lenders to impose hold-up costs. They find that firms pay lower loan interest rate spreads after entering the bond market; that is, after a firm has a bond IPO. Moreover, the interest savings are greater for firms that obtain their first credit rating at the time of their bond IPO, consistent with a smaller increase in public information being associated with the bond IPO for those firms that had a credit rating prior to their bond IPO. In other words, because more information about a firm becomes public when the bond IPO is accompanied by a first-time credit rating, the exploitable informational advantage of a relationship lender is eroded to a greater extent than it is in the case of a firm that already had a credit rating (and thus more public information available) prior to the bond IPO. Schenone (2010) takes a similar approach by focusing on another information-releasing event, an equity IPO, that reduces the ability of a lender with private information to hold up a borrower. Consistent with the bond IPO results, the loan interest rates charged are significantly lower after an equity IPO, as the increased availability of public information about the firm reduces the ability of the relationship lender to extract informational rents.

Given banks' costs associated with collecting and processing information, and with monitoring borrowers subsequent to originating a loan, it is not clear that any rents extracted from relationship firms will be sufficient to provide relationship lenders excess returns. To be value enhancing to the lender, the lending relationship must be profitable to the bank, either directly through the loans, through future business opportunities, or through cross-selling other products and services to borrowers. With respect to the profitability of the loans, Carter et al. 
(2004) find that small banks earn greater risk-adjusted returns on CI loans than do larger banks, concluding that smaller banks have an advantage in small business lending based on soft information. This suggests that small business lending, at least by the smaller banks, is value enhancing to these banks.

On the other hand, Ergungor (2005) interprets his empirical results as being pessimistic about the prospect of relationship lending adding value to banks by profitably exploiting their monopoly position over small, opaque firms. He uses data on small business loans made by community banks to investigate whether banks that were more actively involved in small business lending outperformed those banks that did less small business lending. For small community banks, he finds that the more active small business lenders earned lower riskadjusted income and had business loan portfolios that were less profitable, while finding little difference for large community banks. While providing several caveats, he concludes that relationship loans by community banks likely do not add value to the banks.

In contrast to the studies discussed above, Dahiya, Saunders, and Srinivasan (2003) focus directly on bank valuation. Using event study methods, they investigate the abnormal returns on bank stocks associated with the announcement of a default or bankruptcy by a firm for which the bank serves as a lead bank in a syndicated loan to the distressed firm. They find that the distress announcement is associated with a negative cumulative abnormal return for the lead bank, with the size of the effect being greater (in absolute value) the larger the bank's exposure and the stronger the bank's relationship with the firm. However, several caveats apply. First, because the amount of the loan held by the lead bank is not known, the size of the total loan transaction is used, making it impossible to disentangle the direct losses from the loan from the effects emanating from the loss or damage to the lending relationship. Second, the observations tend to be associated with very large loans and large firms rather than with smaller, bank-dependent firms over which banks can have an exploitable information monopoly from which they can earn economic rents. 


\section{Data}

The data for this study come from four separate sources. The primary data sources are the Federal Reserve's Quarterly Consolidated Financial Statements for Holding Companies (Y9C), the Federal Reserve's Consolidated Reports of Condition and Income for individual banks (call reports), the Federal Reserve's National Information Center database (NIC), and the Center for Research in Security Prices (CRSP).

The sample consists of the set of publicly traded banking organizations. This list is obtained using CRSP data. Using this sample, the daily market price for the common stock of each banking organization and the total number of shares outstanding are used to calculate the average monthly market value of the banking organization. Balance sheet and income data for each bank holding company are obtained from the bank holding company Y9-C reports. Annual data for small business loans are obtained from the small business loan survey section of the June bank call reports (Schedule RC-C Part II). The Small Business Lending Survey is conducted only once per year, beginning in June 1993. Furthermore, some of the key explanatory variables can be consistently collected only starting from 1994. Our sample period ends in 2005, after which the minimum consolidated asset size threshold for Y9-C reporting was raised to $\$ 500$ million. Because the smallest BHCs are the ones that tend to focus most on small business lending, and thus are the main focus for this study, we limit our sample to the period with consistently available data for the smallest BHCs. Therefore, the final sample contains annual observations that begin in 1994 and run through 2005.

The Small Business Lending Survey provides information on loans with original balances of $\$ 1$ million or less in two different loan categories: commercial and industrial loans to U.S. addresses in domestic offices (CI) and commercial real estate loans secured by nonfarm, nonresidential properties in domestic offices (referred to as commercial real estate loans, CRE). In addition, information on farm-related loans with original balances of $\$ 500,000$ or less is also collected for two categories: real estate loans secured by farmland in domestic offices and loans to finance agricultural production in domestic offices. The survey also disaggregates these loans into three size categories based on original loan amounts: less than or equal to $\$ 100,000$, more 
than $\$ 100,000$ through $\$ 250,000$, and more than $\$ 250,000$ through $\$ 1$ million (more than $\$ 250,000$ through $\$ 500,000$ for agricultural and farm loans). This study focuses only on CI and CRE loans to capture the effect of bank-firm relationships on bank value. For publicly traded banking organizations, the portfolio share of loans to farms is typically very small with, on average, less than 1 percent of total assets devoted to agriculture-related loans. In fact, about one-third of our observations have no small farm loans in their portfolios.

Since this study investigates the contribution of relationship lending to the value of banks as evidenced by the market premium placed on small business loans held by the banks, the population of interest here is limited to the sample of publicly traded U.S. banking organizations, whether stand-alone banks, bank holding companies, or, more recently, financial services holding companies, for which market capitalization information is available. Since data on small business loans are available only at the individual bank level and most publicly traded banking organizations are holding companies, the small business loan data must be aggregated to the holding company level. For this purpose, all commercial and savings bank subsidiaries of the holding companies are identified using the Federal Reserve's NIC database.

The sample excludes foreign-owned banks, as well as banks located outside the continental United States. Since announcements of acquisitions may affect market values, and given that we do not have announcement dates for bank or BHC acquisitions to control for those effects, we omit any BHC year during which that BHC acquired another bank or BHC. Finally, the sample excludes observations with extreme values (outliers), defined as observations with values for the dependent or independent variables that are more than four standard deviations away from the variable's mean value. After applying these filters, the sample is an unbalanced panel that includes a total of 2,596 observations on 703 banking organizations.

\section{Specification}

As mentioned earlier, relationship-based finance requires costly information collection and processing by banks, so the additional interest income and fees earned by a relationship 
bank could simply be compensation for its information production efforts. However, if the rents earned due to the informational monopoly power more than compensate the lender for the additional information costs incurred, then relationship loans add value to the bank. Therefore, whether or not relationship lending is value increasing for banks is an empirical question.

The key hypothesis tested in this study is that relationship lending in the form of small business loans held by banking organizations is value enhancing, both in absolute terms and relative to the large loans held by the same banking organizations. In order to test this hypothesis, we must relate small business lending activity to the market value of the banking organization. To do so, it is necessary to relate market value to either the book values of assets and liabilities or the flows of income they produce. One benefit of using book values is the ease of interpreting the estimated coefficients, with the deviation of the estimated coefficient of an asset (liability) component from one (minus one) indicating the value creation or destruction of that activity. However, income measures must be used for off-balance-sheet activities, since the notional values reported in the $\mathrm{Y} 9-\mathrm{C}$ reports by bank holding companies are uninformative about the value of such activities.

The market value of the equity of a banking organization (MVE) is equal to the market value of on-balance-sheet assets (MVA), less the market value of on-balance-sheet liabilities (MVL), plus the net market value of off-balance-sheet activities (MVOBS), plus the market's valuation of other characteristics of the banking organization (MVCHAR), such as management quality and efficiency:

$$
\text { MVE }=\text { MVA }- \text { MVL + MVOBS + MVCHAR. }
$$

Because market values for assets, liabilities, and off-balance-sheet activities are generally not reported by banking organizations, we must replace them with reported measures. For the most part, these are based on amortized cost, which will deviate from market values, with the magnitude of the deviation depending on the economic environment at the time and the quality of the bank's portfolio. ${ }^{5}$ Thus, equation (1) can be rewritten as:

$$
\operatorname{MVE}=\sum \mathrm{a}_{i} \mathrm{~A}_{i}-\sum \mathrm{b}_{j} \mathrm{~L}_{j}+\mathrm{MVOBS}+\mathrm{MVCHAR}+\varepsilon,
$$

\footnotetext{
5 Certain balance sheet items, such as available-for-sale securities, are reported at "fair" value rather than at
} amortized cost. 
where the $\mathrm{A}_{\mathrm{i}}$ 's represent the reported values of various categories of on-balance-sheet bank assets, the Lj's represent the reported values of various categories of on-balance-sheet liabilities, and $\varepsilon$ represents measurement or approximation error. ${ }^{6}$ This empirical framework can be used to infer market values for individual bank asset and liability categories using reported balance sheet and income data for banking organizations. Furthermore, this specification is consistent with previous studies investigating the valuation of banking organizations, for example, Kane and Unal (1990), Venkatachalam (1996), Barth et al. (1998), Flannery and Houston (1999), and Kohlbeck (2004).

This specification allows a disaggregation of the total market premium or discount placed on banks into its components by estimating separate valuation coefficients for the individual portfolio categories of banks. In this framework, the premium or the discount (in the case of negative premiums) that the market places on the respective asset or liability categories is given by ( $\left.a_{i}-1\right)$ for assets and $\left(1-b_{j}\right)$ for liabilities. To the extent that the aís and $b_{j}$ 's differ from unity, the activity associated with the asset or liability category can be thought of as adding value to, or subtracting value from, the banking organization. Since most of these asset and liability holdings are reported at their book values, we expect some of the estimated coefficients to deviate from (plus or minus) unity, reflecting the extent to which the book values of the onbalance-sheet assets and liabilities deviate from their market values. However, the reported values of certain asset and liability categories will be expected not to deviate from their market value. These would include categories reported at fair value, such as securities holdings and tradable assets and liabilities, as well as very short-term maturity categories, such as federal funds sold or purchased.

Why do market participants discount some on-balance-sheet assets and/or liabilities while valuing others at a premium? There are two main sources of such deviations. First, unanticipated changes in prices, interest rates, exchange rates, economic conditions, or borrower credit risk after the bank assets and liabilities have been originated or purchased can

6 Note that the set of asset and liability categories spans the entire balance sheet. Since many categories are correlated with other categories, a specification that excluded some asset or liability categories could suffer from severe omitted variables bias, since the estimated coefficients on the included variables would partially reflect the effects of the omitted (and correlated) categories. 
cause unrecognized (in book values) gains and losses. Second, the economic value of unbooked intangible assets closely associated with on-balance-sheet financial instruments contributes to the market capitalization of these instruments. ${ }^{7}$ Thus, the values of these intangible assets should be included in the market capitalization of the assets or liabilities with which they are associated, causing their market values to deviate from their book values. Examples would include lending relationships and demand deposit relationships, as well as the implicit value of deposit insurance guarantees.

For our purposes, the extent of a bank's existing long-term relationships is assumed to be related to the degree to which a bank participates in small business lending. To the extent that informational asymmetries are likely to be more severe for small firms than for large firms, the use of small business loans as an indicator of long-term bank-firm relationships is appropriate. ${ }^{8}$ Thus, the key identifying assumption used to investigate the value of lending relationships to banks is that such value is reflected in the relative valuations of small business loans compared with the valuations of loans to larger firms.

Consequently, the specific focus of the study is on the estimated values of the ai's associated with bank holdings of small business loans. The key hypothesis tests are whether these estimated coefficients are significantly greater than unity and whether the effects on a bank's market valuation differ significantly from the effects of large loans of the same type. If so, then small business lending adds to the market value of banking organizations, either in absolute terms, relative to large loans, or both. It is important to consider the relative as well as the absolute effects because by focusing on the differential effect compared with the effect from large loans, the specification better controls for the average effects of changes in the economic environment (such as business cycles, unexpected changes in interest rates, etc.) on all business loans.

7 Under Generally Accepted Accounting Principles (GAAP), intangible assets are not recorded unless they are purchased as part of a business combination transaction.

8 Technically, these are small loans rather than small business loans. For the most part, such small CI and CRE loans (less than $\$ 1$ million) are made primarily to small businesses. However, these loans represent only the smaller tail of the distribution of loans made to small businesses. It is likely that many small business loans are substantially larger than $\$ 1$ million. 
Although we include two categories of small business loans, CI and CRE, given the different natures of these two loan categories, the primary focus is on small CI loans. Small CI loans fit the category of relationship loans better, although many of the larger banks make such loans on a transactional basis using credit scoring models. Therefore, we might anticipate that small CI loans would be value enhancing for small and perhaps even mid-sized banks, but less so for larger banks. On the other hand, small CRE loans tend to be transactional loans, since they are a form of asset-based lending with real estate serving as collateral. Therefore, we might not expect such lending to be particularly value enhancing to the lender, insofar as such lending tends not to be based on private information arising from long-term relationships. However, it is possible that economies of scale might provide economic rents from such loans to the larger banking organizations.

To make equation (2) operational, we still need to specify the dependent variable, the various categories of on-balance-sheet assets and liabilities, off-balance-sheet activities, and the other relevant characteristics of the banking organizations. Furthermore, to account for heteroscedasticity, we divide each balance sheet variable in the equation, as well as the proxy for off-balance sheet items, the constant term, and the error term, by the book value of equity (BV), measured as total equity capital less perpetual preferred stock and related surplus.

\section{Dependent variable}

The dependent variable (MVBV) is the market value of equity of the banking organization divided by its book value. The banking data are measured as of the end of June, but they do not become publicly available until approximately September. However, publicly traded banking organizations also are required by the Securities and Exchange Commission to file 10-Q forms, which tend to become available earlier, although they contain less detail about the $\mathrm{BHC}^{\prime} \mathrm{s}$ balance sheet. Consequently, we use the average of the daily market values for September, although we obtain the same qualitative results if we use market values for August.

\section{On-balance-sheet assets and liabilities}

Each of these measures is based on the June (bank or bank holding company) call reports and has been scaled by the book value of equity. The asset categories include four types 
of loans secured by real estate: commercial (nonfarm, nonresidential) real estate loans (CRE), construction, land development, and other land loans (CSTR), one-to-four family residential loans (RES), and multifamily residential loans (MULT). Loans secured by farmland are combined with loans to finance agricultural production and other loans to farmers (FARM). The asset categories also include commercial and industrial loans (CI), credit card loans (CCD), other (non-credit card) consumer loans (CONS), and other loans and leases less unearned income on loans (OTHLNSLEAS), with the latter including all remaining loan types, such as loans to depository institutions, foreign loans and loans to foreign governments, and leases. In addition to total CRE loans and total CI loans, we also include small business commercial real estate loans (SMCRE) and small business commercial and industrial loans (SMCI), with the estimated effects on these two categories reflecting any differential effect of small business loans relative to larger loans. For some specifications, the small loan measures are further subdivided into the smallest size category of loans, those with original amounts of $\$ 100,000$ or less (SM1CI, SM1CRE), and the remaining small business loans with original amounts of more than $\$ 100,000$ through \$1 million (SM23CI, SM23CRE).

In addition to these loan categories, we include securities at fair value (SEC), trading assets (TRADA), reserves (RESV), net federal funds sold and securities repurchased under agreements to resell (FF), and two categories of other assets (OTHA1 and OTHA2). OTHA1 includes other real estate owned, premises and fixed assets, and intangible assets, while OTHA2 includes the bank's unearned income on all types of loans, the bank's investments in unconsolidated subsidiaries and associated companies, customers' liability on acceptances outstanding, and other assets. In addition, we include two measures of problem loans, nonperforming loans and other assets (NPL) and the loan loss reserve (LLR). Liability components include core deposits (CORE), other deposits (OTHDEP), trading liabilities (TRADL), and all other liabilities (OTHLIAB). Finally, to control for the interest rate risk exposure of on-balance-sheet assets and liabilities, we include GAP, measured as earning assets that mature or are repriceable within one year, less interest-bearing liabilities that mature or are repriceable within one year. Because the interest rate environment differs from year to year, the implications of GAP for the value of a banking organization may differ from year to year. Thus, 
we interact GAP with the set of year dummy variables in order to allow GAP to have a different estimated coefficient each year.

Off-balance-sheet activities

Off-balance-sheet activities are measured using the fee income generated by these activities and the variable is scaled by BV (FEE). This variable includes total noninterest income less any items not attributable to off-balance-sheet activities, such as service charges on deposit accounts, net gains on sales of loans and leases, and net gains on sales of other real estate owned. To control for the effect of the volatility of fee income on bank market value, we include the annualized eight-quarter standard deviation of FEE scaled by the annualized eight-quarter mean of FEE (sdFEE). We also include FEE interacted with sdFEE.

\section{Other bank characteristics}

The set of other bank characteristics includes the logarithm of total real assets (LASSETS), operating (noninterest) expense relative to total income (OPEXP), the sum of trading assets and trading liabilities divided by total assets (SHTRADAL), and the logarithm of the Herfindahl index (LHERF), computed using the assets of the individual bank subsidiaries of the banking organization to reflect the concentration of the organizational structure of the banking organization. ${ }^{9}$ For consistency of the estimated equation with equation (2), one can think of each variable in the vector MVCHAR as having been multiplied by BV, so that BV cancels out when all variables in the equation are scaled by BV.

\section{Coefficient restrictions}

As noted above, a subset of the on-balance-sheet asset and liability categories as reported on the call reports can be treated as approximating market values. Thus, the expected coefficients of this subset should be equal to one (for asset components) or minus one (for liability components). Because the components of the asset and liability categories exhibit substantial correlations with each other in many instances, we restrict the estimated coefficients of these asset and liability components to one or minus one, respectively. The set of variables so

9 As an alternative measure to LHERF, we also considered a measure of the logarithm of the average size (using assets) of the bank subsidiaries of the banking organization. The results were not sensitive to this change in specification. 
constrained includes RESV, SEC, FF, TRADA and TRADL. We were not able to reject these restrictions, as none of the estimated coefficients in the unrestricted specification was statistically significantly different from one (minus one for TRADL).

Table 1 presents the distribution of BHC observations by year for all BHCs and by asset size class. Table 2 presents information about small business loans as a percentage of total loans in the same category for CI loans and for CRE loans. The information includes the shares for total small business loans as well as disaggregated into the three loan-size subcategories. The data also are shown for the full sample period and for three subperiods to provide a sense of the extent to which the shares may have changed over time.

\section{Estimation Results}

Table 3 contains the means, standard deviations, and minimum and maximum values for each of the variables used in the regression equations, with each variable described in the appendix. Outliers, defined as those observations more than four standard deviations from the mean value for each variable, have been removed. In addition to the set of explanatory variables discussed above, each equation includes a set of annual dummy variables in order to control for effects emanating from general macroeconomic conditions, such as interest rates, the business cycle, and changes in stock price indexes. To account for any correlation of residuals for a given BHC across years, we use clustered standard errors.

Table 4 contains the estimates for the base regression. Column 1 contains the estimates for all banking organizations in our sample, while columns 2, 3, and 4 contain subsets of BHCs based on BHC asset-size classes. The point estimates for the loan categories tend to be very close to unity, although a few of the estimated coefficients do differ significantly from unity, as indicted by the "a" and " $b$ " superscripts. For the total sample, both CSTR and FARM have estimated coefficients that differ significantly from unity, indicating that they add value to the BHC; that is, holding an additional dollar of such loans increases the market value of the bank by more than one dollar. For the loan categories having effects that differ significantly from unity for the subsets of BHCs based on asset size class, CI has an estimated coefficient below 
unity for the smallest size category, and CRE, CSTR, FARM, and CONS each have effects above unity for medium-sized banking organizations.

With respect to the value-enhancing characteristics of small business loans, column 1 indicates that each dollar of small CI loans held in a bank's portfolio adds 16 cents to the market value of the banking organization relative to large CI loans, with the difference being statistically significant. Summing the estimated coefficients on CI and SMCI indicates an absolute effect of

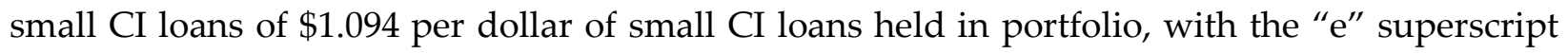
indicating that the effect differs significantly from unity. Thus, small CI loans add an additional 9.4 cents, on average, to the value of the BHC per dollar of small CI loans held in portfolio. The differential effect of SMCI is the largest for the smallest banking organizations (assets $<\$ 500$ million in constant 2005 dollars), with the differential effect being statistically significant (column 2). For these smallest BHCs, a dollar of small CI loans held in a bank's portfolio adds 26.4 cents to the market value of the banking organization relative to large CI loans. Summing the SMCI and CI coefficients indicates that the total effect on a BHC's market value of small CI loans is an additional 11.5 cents per dollar of loans, with the effect being statistically significant. The differential effect of SMCI also is positive for medium banks (column 3), although significant only at the 10 percent level. However, the total effect of 1.132 differs significantly from unity, indicating that small CI loans increase the market value of medium-sized BHCs. In contrast, and as might be expected, when we consider only the largest banking organizations (assets $>\$ 1.5$ billion), shown in column 4 , the size of the estimated coefficient on SMCI is of a smaller magnitude, and the effect is not statistically significant. These results suggest that the value-enhancing effect of small CI loans comes, in large part, from the smaller banking organizations where relationship lending is most prevalent.

These results are consistent with relationship lending adding value to BHCs. For small and perhaps medium-sized BHCs, it appears that their expertise in originating and monitoring small CI loans does add to their market value, as these banks exploit the private information about smaller, opaque borrowers accumulated over the course of long-term relationships. Because one would expect relationship lending to be much less prevalent at the largest banks, which tend to use credit scoring models, a transactions technology, to originate many of their 
small CI loans, it is not surprising that the value-enhancing effects occur predominately at the smaller banking organizations. Moreover, the value-enhancing effects suggested by the estimated coefficients on SMCI may reflect more than just the profitability of holding the loans, insofar as the estimated effects also capture the profitability of other lines of business with their relationship firms.

Column 1 indicates that CRE loans have a value-enhancing effect of about 2.2 cents for each dollar of CRE loans held in a banking organization's portfolio. However, the point estimates across the BHC size classes indicate that CRE loans are value enhancing only for medium-sized BHCs, given that this is the only estimated coefficient that differs significantly from unity. Furthermore, the statistically insignificant estimated coefficient on SMCRE indicates that small CRE loans have no differential effect over and above that of large CRE loans, although the total effect of small CRE loans is value enhancing for medium-sized BHCs, as indicated by the " $\mathrm{f}$ " superscript.

However, the result that small CRE loans do not add value to banks relative to large CRE loans should not be particularly surprising, since CRE loans are asset-based loans originated using a transactions technology rather than being relationship based, so the superior information that arises from lending relationships is less important for these loans than for CI lending. In other words, the primary determinant of the origination decision is the quality of the collateral for the loan, rather than private information about the borrower accumulated through a long-term relationship.

With respect to the other components of the asset side of the balance sheet, the estimated coefficient on OTHA1 differs significantly from unity for all BHCs, as well as for medium and large BHCs, which suggests that the market value of OTHA1 is less than its book value. This is not surprising, given that OTHA1 includes other real estate owned, goodwill, and other intangible assets, each of which is likely to be valued below its reported book value. With respect to measures of problems in the asset portfolio, the estimated coefficients on nonperforming loans are negative, as expected, while the estimated coefficients on the loan loss reserve are inconsistently signed, although none is statistically significant. However, it is not clear which sign these coefficients should have. One might expect a positive coefficient, insofar 
as they represent an asset held against nonperforming loans. On the other hand, to the extent that banks systematically under-reserve for problem loans, each dollar of LLR would indicate additional amounts of unreserved-for problem loans, suggesting a negative coefficient.

With respect to liabilities, each of the estimated coefficients is negative, as expected. Also as anticipated, core deposits are value enhancing for banking organizations, with each dollar of core deposits adding 9.7 cents to the market value of the bank for the full sample. Interestingly, core deposits add more per dollar to the value of the largest banks, with the value-enhancing effect being statistically significant (differing significantly from minus unity) for all bank size categories. On the other hand, other liabilities have point estimates that suggest that they reduce the market value of the BHCs, with the estimated coefficients differing significantly from minus unity in each instance, except those for large banks.

Off-balance-sheet activities, using FEE as the proxy, produce significant positive effects for all but the small BHC sample, perhaps because off-balance-sheet activities represent a less important component of small BHC activities. While the effect of the volatility of fee income is never significant, its interaction with FEE is statistically significant for medium-sized banks, suggesting that the effect of fee income is mitigated for medium-sized banks by volatility.

With respect to the other bank characteristics, unsurprisingly, a higher ratio of operating expenses relative to total income reduces market value relative to book value, with the adverse effect being greater the larger the bank size class. Point estimates suggest that a higher proportion of trading assets and liabilities reduces market value relative to book value for medium-sized and large BHCs. Given that small BHCs tend not to be heavily engaged in propriety trading, it is not surprising that the estimated coefficient for small BHCs is statistically insignificant. One explanation for the value-reducing effect of trading assets and liabilities is that such assets and liabilities are viewed as riskier and/or less transparent, and thus are discounted more. Finally, the concentration of bank subsidiaries within a banking organization, as reflected in LHERF, has a positive effect on the market value of a banking organization. While the estimated coefficients are not statistically significant at usual levels of significance, the coefficient for large BHCs is significant at the 10 percent level, likely reflecting the increased efficiency that can be achieved by consolidating bank subsidiaries. 
To save space, the table omits the estimated coefficients on the set of year dummy variables interacted with the measure of interest rate risk, GAP. As expected, the magnitude of the effect varies from year to year as the interest rate environment changed. Early in our sample period, the effect was negative as interest rates rose. Then, as interest rates leveled off and began to fall, the effect turned positive. Then, after interest rates began to rise at the end of the 1990s, the GAP effect again turned negative.

Table 5 further investigates the impact of small business lending on the market value of banking organizations by disaggregating small business loans into two size categories in order to isolate the effects of the smallest category of reported loans that likely contain most of the loans originated using credit scoring models at the larger banks. The prefixes on CI and CRE indicate the size class, with SM1 referring to the smallest size class (equal to or less than $\$ 100,000)$, and SM23 referring to the combination of the other two size classes (above $\$ 100,000$ through $\$ 250,000$, and above $\$ 250,000$ through $\$ 1$ million). For the set of all banks (column 1), neither of the individual small business loan categories has a statistically significant impact. In part, the general lack of significance of the small loan effects may reflect the strong correlation between the two components of small loans of a given loan category. Strikingly, the only statistically significant estimated coefficient on small loans is for SM1CI for the small BHC category, which represents precisely those BHCs most likely to rely on relationship lending rather than credit scoring. In fact, the total effect of SM1CI for small BHCs is 1.395, differing significantly from unity. Thus, for small BHCs, holding an additional dollar of such CI loans adds 39.5 cents to the value of the BHCs. While this seems high, keep in mind that this estimated effect likely captures the effect of the profitability of multiple lines of business with their relationship borrowers. In contrast, the table shows no indication that CI loans of $\$ 100,000$ or less add value to the medium-sized and largest BHCs that tend to use credit scoring technology more intensively for their small business loans. Moreover, the table shows no indication that small CRE loans, being primarily transactional rather than relationship based, provide additional value. These results provide further evidence that relationship lending can be an important source of value to a banking organization. 


\section{Concluding Comments}

This study investigates the extent to which relationship lending enhances the market value of banking organizations. We use data on small business loans, defined as commercial and industrial loans and commercial real estate loans with an original value of $\$ 1$ million or less, as our proxy for small business loans. We find that small CI loans do add market value to small and medium-sized banking organizations. This suggests that at least for small and medium-sized banks, the added revenue associated with relationship lending exceeds the added information costs associated with evaluating and monitoring small business loans, although the estimated effect also may include the value of relationships emanating from the opportunity to profit from other lines of business with their relationship firms. Furthermore, the value-enhancing effect for the smallest BHCs appears to arise primarily from the smallest size category of CI loans, those with original amounts of $\$ 100,000$ or less. Such loans likely represent the loans made to small, opaque firms over which these BHCs are most likely to be able to exploit informational monopoly power.

In contrast, small CRE loans do not appear to enhance the market value of BHCs beyond that from CRE loans generally, even for the smallest set of banks. One explanation for the contrast of this result with that for small CI loans is that CRE loans represent transactional rather than relationship lending, and, being based on collateral rather than superior private information about relationship borrowers, make the advantages arising from informationintensive relationship lending based on soft information less important.

Our direct evidence that small business lending is a profitable market niche for small and possibly medium-sized publicly traded banking organizations in the United States suggests that such banks should actively participate in lending to small businesses. The evidence is consistent with these banks having a comparative advantage in originating and monitoring small business loans compared to larger banking organizations. Consequently, consolidation of the banking industry, insofar as it takes the form of the acquisition of smaller banking organizations by larger banking organizations that are less focused on small business lending, 
may be value destroying, and thus not in the interests of the shareholders of the acquiring banking organizations. 


\section{References}

Barth, M. E., W. H. Beaver, and W. R. Landsman. 1998. “Relative Valuation Roles of Equity Book Value and Net Income as a Function of Financial Health, Journal of Accounting and Economics, 25, 1-34.

Berger, A. N., and L. K. Black. 2011. “Bank Size, Lending Technologies, and Small Business Finance," Journal of Banking and Finance, 35, 724-35.

Berger, A. N., A. M. Cowen, and W. S. Frame. 2011. “The Surprising Use of Credit Scoring in Small Business Lending by Community Banks and the Attendant Effects on Credit Availability, Risk, and Profitability," Journal of Financial Services Research, 39, 1-17.

Berger, A. N., W. S. Frame, and N. H. Miller. 2005. "Credit Scoring and the Availability, Price, and Risk of Small Business Credit," Journal of Money, Credit, and Banking, 37, April, 191-222.

Berger, A. N., N. H. Miller, M. A. Petersen, R. G. Rajan, and J. C. Stein. 2005. “Does Function Follow Organizational Form? Evidence from the Lending Practices of Large and Small Banks," Journal of Financial Economics, 76, 237-269.

Berger, A. N., and G. F. Udell. 1995. "Relationship Lending and Lines of Credit in Small Firm Finance," Journal of Business, 68, 351-382.

Berger, A. N., and G. F. Udell. 2002. "Small Business Credit Availability and Relationship Lending: The Importance of Bank Organizational Structure," The Economic Journal, 112, February, F32-F53.

Berger, A. N., and G. F. Udell. 2006. “A More Complete Conceptual Framework for SME Finance," Journal of Banking and Finance, 30, 2945-2966.

Berlin, M., and L. J. Mester. 1999. "Deposits and Relationship Lending," The Review of Financial Studies, 12(3), 579-560.

Berlin, M., and L. J. Mester. 1998. "On the Profitability and Cost of Relationship Lending," Journal of Banking and Finance, 22, 873-897.

Bharath, S., S. Dahiya, A. Saunders, and A. Srinivasan. 2007. "So What Do I Get? The Bank's View of Lending Relationships," Journal of Financial Economics, 85, 368-419.

Bharath, S., S. Dahiya, A. Saunders, and A. Srinivasan. 2011. "Lending Relationships and Loan Contract Terms," The Review of Financial Studies, 24(4), 1141-1203.

Boot, A. W. A. 2000. “Relationship Banking: What Do We Know?" Journal of Financial Intermediation, 9, 7-25.

Carter, D. A., J. E. McNulty, and J. A. Verbrugge. 2004. “Do Small Banks Have an Advantage in Lending? An Examination of Risk-Adjusted Yields on Business Loans at Large and Small Banks," Journal of Financial Services Research, 25(2/3), April-June, 233-252.

Cole, R. A. 1998. "The Importance of Relationships to the Availability of Credit," Journal of Banking and Finance, 22, 959-977. 
Cole, R. A., L. G. Goldberg, and L. J. White. 2004. "Cookie-Cutter vs. Character: The Micro Structure of Small Business Lending by Large and Small Banks," Journal of Financial and Quantitative Analysis, 39(2), June, 227-251.

Dahiya, S., M. Puri, and A. Saunders. 2003. "Bank Borrowers and Loan Sales: New Evidence on the Uniqueness of Bank Loans," Journal of Business, 76, 563-582.

Dahiya, S., A. Saunders, and A. Srinivasan. 2003. "Financial Distress and Bank Lending Relationships," The Journal of Finance, 58(1), 375-399.

Degryse, H., and P. Van Cayseele. 2000. "Relationship Lending within a Bank-Based System: Evidence from European Small Business Data," Journal of Financial Intermediation, 9, 90-109.

DeYoung, R., W. S. Frame, D. Glennon, and P. Nigro. 2011. "The Information Revolution and Small Business Lending: The Missing Evidence," Journal of Financial Services Research, 39, 1933.

DeYoung, R., D. Glennon, and P. Nigro. 2005. "Borrower-Lender Distance, Credit Scoring, and the Performance of Small Business Loans," Proceedings of the $41^{\text {st }}$ Annual Conference on Bank Structure and Competition, Federal Reserve Bank of Chicago.

DeYoung, R., D. Glennon, and P. Nigro. 2008. "Borrower-Lender Distance, Credit Scoring, and Loan Performance: Evidence from Informational-Opaque Small Business Borrowers," Journal of Financial Intermediation, 17, 113-43.

DeYoung, R., W. C. Hunter, and G. F. Udell. 2004. “The Past, Present, and Probable Future fro Community Banks," Journal of Financial Services Research, 25(2/3), April-June, 85-133.

Ergungor, O. E. 2005. “The Profitability of Bank-Borrower Relationships," Journal of Financial Intermediation, 14(4), October, 485-512.

Flannery, M. J., and J. F. Houston. 1999. "Value of a Government Monitor for U.S. Banking Firms," Journal of Money, Credit, and Banking, 31(1), 14-34.

Hale, G., and J.A. C. Santos, 2009. “Do Banks Price Their Informational Monopoly?” Journal of Financial Economics, 93, 185-206.

Ioannidou, V., and S. Ongena. 2010. "Time for a Change: Loan Conditions and Bank Behavior when Firms Switch Banks," The Journal of Finance, 65(5), 1847-1877.

James, C., and P. Wier. 1990. “Borrowing Relationships, Intermediation, and the Cost of Issuing Public Securities," Journal of Financial Economics, 28, 149-171.

James, C. 1987. "Some Evidence on the Uniqueness of Banks," Journal of Financial Economics, 19, 217-235.

Kane, E. J., and H. Unal. 1990. "Modeling Structural and Temporal Variation in the Market's Valuation of Banking Firms," The Journal of Finance, 45(1), 113-136.

Kohlbeck, M. 2004. “Investor Valuations and Measuring Bank Intangible Assets," Journal of Accounting, Auditing, and Finance, 19 (Winter), 29-60. 
Ljungqvist, A., F. Marston, and W. J. Wilhelm, Jr. 2006. “Competing for Securities Underwriting Mandates: Banking Relationships and Analyst Recommendations," The Journal of Finance, 61(1), 301-340.

Mester, L., L. Nakamura, and M. Renault. 1998. "Checking Accounts and Bank Monitoring," Federal Reserve Bank of Philadelphia, Working Paper.

Nakamura, L. 1993. "Commercial Bank Information: Implications for the Structure of Banking," in Structural Change in Banking, edited by M. Klausner and L. White, Irwin Publishing, IL, $131-160$.

Petersen, M., and R. Rajan. 1994. "The Benefits of Firm-Credit Relationships: Evidence from Small Business Data," The Journal of Finance, 49(1), 3-37.

Rajan, R. 1992. "Insiders and Outsiders: The Choice between Informed and Arm's Length Debt," The Journal of Finance, 47, 1367-1400.

Santos, J. A. C., and A. Winton. 2008. “Bank Loans, Bonds, and Information Monopolies across the Business Cycle," The Journal of Finance, 63(3), 1315-1359.

Schenone, C. 2010. “Lending Relationships and Information Rents: Do Banks Exploit Their Information Advantages?" The Review of Financial Studies, 23(3), 1149-1199.

Sharpe, S. 1990. “Asymmetric, Information, Bank Lending, and Implicit Contracts: A stylized Model of Customer Relationships," The Journal of Finance, 45, 1069-1087.

Slovin, M. B., M. A. Shuska, and J. A. Polonchek. 1993. "The Value of Bank Durability: Borrowers as the Bank Stakeholders," The Journal of Finance, 48, 247-266.

Stein, J. C. 2002. "Information Production and Capital Allocation: Decentralized versus Hierarchical Firms," The Journal of Finance, 57(5), October, 1891-1921.

Udell, G. 1997. "The Consolidation of the Banking Industry and Small Business Lending," in Bank Mergers and Acquisitions, edited by Amihud and Miller, Stern Kluwer Publishers, 221-235.

Venkatachalam, M. 1996. "Value-Relevance of Banks' Derivatives Disclosures," Journal of Accounting and Economics, 22, 327-355.

Yasuda, A. 2005. “Do Bank Relationships Affect the Firm's Underwriter Choice in the Corporate-Bond Underwriter Market?" The Journal of Finance, 60(3), 1259-1292. 
Table 1 Distribution of BHC observations by asset size and by year

Number of observations

All BHCs

Total 1994

1995

1996

1997

1998

1999

2000

2001

2002

2003

2004

2005

Assets below $\$ 500$ million

$2,596 \quad 146$

16
55

196

192

207

201

195

238

261

272

$\$ 500$ million - $\$ 1.5$ billion

1,091

55

Above $\$ 1.5$ billion

742

57
47

43

76
57

78
47

74

84
48

103

Source: Y9-C, call reports, authors' calculations 
Table 2. Small business loans, scaled by total loans in corresponding category

\begin{tabular}{|c|c|c|c|}
\hline & \multicolumn{3}{|c|}{ BHC Asset category (in \$ 2005) } \\
\hline & $\begin{array}{c}\text { Below } 500 \\
\text { million }\end{array}$ & $\begin{array}{c}500 \text { million - } \\
1.5 \text { billion }\end{array}$ & $\begin{array}{c}\text { Above } 1.5 \\
\text { billion }\end{array}$ \\
\hline & \multicolumn{3}{|c|}{ Entire sample period } \\
\hline Number of observations & 763 & 1,091 & 742 \\
\hline Total small CI loans & $78.71(\%)$ & $68.78(\%)$ & $52.71(\%)$ \\
\hline - below $\$ 100,000$ & 29.45 & 24.63 & 17.35 \\
\hline - between $\$ 100,000$ and $\$ 250,000$ & 19.36 & 16.15 & 11.80 \\
\hline - between $\$ 250,000$ and $\$ 1$ million & 29.90 & 28.00 & 23.56 \\
\hline Total small CRE loans & 66.93 & 56.69 & 45.70 \\
\hline - below $\$ 100,000$ & 7.32 & 6.78 & 5.01 \\
\hline - between $\$ 100,000$ and $\$ 250,000$ & 15.82 & 13.66 & 10.62 \\
\hline \multirow[t]{2}{*}{ - between $\$ 250,000$ and $\$ 1$ million } & 43.79 & 36.25 & 30.07 \\
\hline & \multicolumn{3}{|c|}{ 1994-1997 } \\
\hline Number of observations & 227 & 280 & 194 \\
\hline Total small CI loans & 76.86 & 68.28 & 53.85 \\
\hline - below $\$ 100,000$ & 30.58 & 26.36 & 18.88 \\
\hline - between $\$ 100,000$ and $\$ 250,000$ & 18.24 & 16.24 & 11.69 \\
\hline - between $\$ 250,000$ and \$1 million & 28.04 & 25.68 & 23.28 \\
\hline Total small CRE loans & 69.05 & 60.71 & 52.03 \\
\hline - below $\$ 100,000$ & 8.48 & 9.03 & 6.86 \\
\hline - between $\$ 100,000$ and $\$ 250,000$ & 17.07 & 15.44 & 12.39 \\
\hline \multirow[t]{2}{*}{ - between $\$ 250,000$ and $\$ 1$ million } & 43.50 & 36.24 & 32.78 \\
\hline & \multicolumn{3}{|c|}{$1998-2001$} \\
\hline Number of observations & 288 & 344 & 209 \\
\hline Total small CI loans & 80.03 & 70.07 & 52.92 \\
\hline - below $\$ 100,000$ & 31.91 & 25.63 & 18.79 \\
\hline - between $\$ 100,000$ and $\$ 250,000$ & 19.25 & 15.97 & 11.75 \\
\hline - between $\$ 250,000$ and \$1 million & 28.87 & 28.47 & 22.38 \\
\hline Total small CRE loans & 67.06 & 60.55 & 48.77 \\
\hline - below $\$ 100,000$ & 8.36 & 7.64 & 6.05 \\
\hline - between $\$ 100,000$ and $\$ 250,000$ & 16.44 & 14.99 & 11.90 \\
\hline \multirow[t]{2}{*}{ - between $\$ 250,000$ and $\$ 1$ million } & 42.26 & 37.92 & 30.82 \\
\hline & \multicolumn{3}{|c|}{$2002-2005$} \\
\hline Number of observations & 248 & 467 & 339 \\
\hline Total small CI loans & 78.86 & 68.13 & 51.93 \\
\hline - below $\$ 100,000$ & 25.57 & 22.84 & 15.60 \\
\hline - between $\$ 100,000$ and $\$ 250,000$ & 20.50 & 16.22 & 11.90 \\
\hline - between $\$ 250,000$ and $\$ 1$ million & 32.79 & 29.07 & 24.43 \\
\hline Total small CRE loans & 64.84 & 51.45 & 40.18 \\
\hline - below $\$ 100,000$ & 5.04 & 4.80 & 3.30 \\
\hline - between $\$ 100,000$ and $\$ 250,000$ & 13.96 & 11.62 & 8.82 \\
\hline - between $\$ 250,000$ and $\$ 1$ million & 45.84 & 35.03 & 28.06 \\
\hline
\end{tabular}

Source: Y9-C, call reports, authors' calculations 
Table 3: Summary statistics

\begin{tabular}{|c|c|c|c|c|c|}
\hline Variable & Obs & Mean & Std. Dev. & Min & Max \\
\hline MVBV & 2,596 & 1.8439 & 0.6658 & 0.2224 & 6.0025 \\
\hline CI & 2,596 & 1.2558 & 0.9005 & 0.0000 & 5.3376 \\
\hline SMCI & 2,596 & 0.7746 & 0.5618 & 0.0000 & 3.3342 \\
\hline SM1CI & 2,596 & 0.2450 & 0.2049 & 0.0000 & 2.2398 \\
\hline SM23CI & 2,596 & 0.5296 & 0.4231 & 0.0000 & 2.8727 \\
\hline CRE & 2,596 & 1.9984 & 1.1565 & 0.0006 & 7.8357 \\
\hline SMCRE & 2,596 & 1.0836 & 0.7002 & 0.0000 & 4.2863 \\
\hline SM1CRE & 2,596 & 0.1059 & 0.1111 & 0.0000 & 1.1599 \\
\hline SM23CRE & 2,596 & 0.9777 & 0.6571 & 0.0000 & 4.1283 \\
\hline CSTR & 2,596 & 0.5899 & 0.6407 & 0.0000 & 4.3711 \\
\hline RES & 2,596 & 2.5159 & 1.5947 & 0.0087 & 9.7667 \\
\hline MULT & 2,596 & 0.2006 & 0.2764 & 0.0000 & 2.4660 \\
\hline FARM & 2,596 & 0.1235 & 0.2297 & 0.0000 & 1.3307 \\
\hline CCD & 2,596 & 0.0643 & 0.1257 & 0.0000 & 1.2934 \\
\hline CONS & 2,596 & 0.6549 & 0.6638 & 0.0000 & 3.3889 \\
\hline OTHLNSLEAS & 2,596 & 0.1517 & 0.2200 & 0.0000 & 1.8890 \\
\hline SEC & 2,596 & 2.9281 & 1.5540 & 0.0000 & 9.9471 \\
\hline TRADA & 2,596 & 0.0081 & 0.0505 & 0.0000 & 1.0171 \\
\hline RESV & 2,596 & 0.4775 & 0.2626 & 0.0308 & 2.0910 \\
\hline $\mathrm{FF}$ & 2,596 & -0.1424 & 0.6651 & -3.0261 & 2.8167 \\
\hline OTHA1 & 2,596 & 0.2878 & 0.1571 & 0.0152 & 1.2622 \\
\hline OTHA2 & 2,596 & 0.3070 & 0.1802 & 0.0316 & 1.7400 \\
\hline NPL & 2,596 & 0.0654 & 0.0668 & 0.0000 & 0.5948 \\
\hline LLR & 2,596 & 0.1089 & 0.0460 & 0.0091 & 0.3877 \\
\hline CORE & 2,596 & 5.2206 & 1.7871 & 0.2349 & 13.6337 \\
\hline OTHDEP & 2,596 & 3.9636 & 1.6007 & 0.1145 & 10.8414 \\
\hline TRADL & 2,596 & 0.0018 & 0.0213 & 0.0000 & 0.7334 \\
\hline OTHLIAB & 2,596 & 1.1072 & 1.0944 & 0.0116 & 6.6894 \\
\hline FEE & 2,596 & 0.0703 & 0.0716 & 0.0010 & 0.5690 \\
\hline sdFEE & 2,596 & 0.4039 & 0.5515 & 0.0375 & 22.3602 \\
\hline LASSETS & 2,596 & 13.9228 & 1.1480 & 10.9338 & 19.2743 \\
\hline OPEXP & 2,596 & 0.4179 & 0.1016 & 0.1216 & 0.8517 \\
\hline SHTRADAL & 2,596 & 0.0008 & 0.0055 & 0.0000 & 0.1187 \\
\hline LHERF & 2,596 & 9.0130 & 0.4358 & 5.9957 & 9.2103 \\
\hline GAP & 2,596 & 0.4807 & 2.6595 & -10.1626 & 8.7580 \\
\hline
\end{tabular}

Note: Variables described in Appendix.

Source: Y9-C, call reports, authors' calculations 
Table 4: Determinants of market value of banking organizations: full sample and by BHC size

\begin{tabular}{|c|c|c|c|c|}
\hline & $\begin{array}{c}\text { All BHCs } \\
\text { (1) }\end{array}$ & $\begin{array}{l}\text { Assets below } 0.5 \\
\text { billion } \$ 2005 \\
\text { (2) }\end{array}$ & $\begin{array}{l}\text { Assets between } 0.5 \\
\text { and } 1.5 \text { billion } \$ 2005 \\
\text { (3) }\end{array}$ & $\begin{array}{c}\text { Assets above } 1.5 \\
\text { billion } \$ 2005 \\
\text { (4) }\end{array}$ \\
\hline \multirow[t]{2}{*}{ CI } & $0.934 * *$ & $0.851^{* *, \mathrm{~b}}$ & $0.982^{* *}$ & $0.952 * *$ \\
\hline & $(0.037)$ & $(0.069)$ & $(0.046)$ & $(0.069)$ \\
\hline \multirow[t]{2}{*}{ SMCI } & $0.160^{* *}, \mathrm{e}$ & $0.264^{* *}, \mathrm{e}$ & $0.150^{f}$ & 0.098 \\
\hline & $(0.050)$ & $(0.081)$ & $(0.078)$ & $(0.126)$ \\
\hline \multirow[t]{2}{*}{ CRE } & $1.022^{* *}$ & $1.035 * *$ & $1.078 * *, \mathrm{~b}$ & $0.906 * *$ \\
\hline & $(0.028)$ & $(0.038)$ & $(0.037)$ & $(0.062)$ \\
\hline \multirow[t]{2}{*}{ SMCRE } & 0.003 & 0.004 & $0.010^{f}$ & 0.113 \\
\hline & $(0.037)$ & $(0.053)$ & $(0.057)$ & $(0.099)$ \\
\hline \multirow[t]{2}{*}{ CSTR } & $1.097 * *$, a & $1.079 * *$ & $1.145^{* *}$, a & $1.135^{* *}$ \\
\hline & $(0.034)$ & $(0.046)$ & $(0.041)$ & $(0.073)$ \\
\hline \multirow[t]{2}{*}{ RES } & $1.012^{* *}$ & $1.007 * *$ & $1.034^{* *}$ & $1.031 * *$ \\
\hline & $(0.018)$ & $(0.027)$ & $(0.023)$ & $(0.037)$ \\
\hline \multirow[t]{2}{*}{ MULT } & $1.004^{* *}$ & $0.951 * *$ & $1.076^{* *}$ & $1.016 * *$ \\
\hline & $(0.062)$ & $(0.087)$ & $(0.081)$ & $(0.118)$ \\
\hline \multirow[t]{2}{*}{ FARM } & $1.156^{* *}, \mathrm{~b}$ & $1.155^{* *}$ & $1.214^{* *}$, a & $1.172 * *$ \\
\hline & $(0.070)$ & $(0.118)$ & $(0.085)$ & $(0.139)$ \\
\hline \multirow[t]{2}{*}{ CCD } & $0.930^{* *}$ & $1.261^{* *}$ & $0.881^{* *}$ & $0.964 * *$ \\
\hline & $(0.146)$ & $(0.301)$ & $(0.315)$ & $(0.144)$ \\
\hline \multirow[t]{2}{*}{ CONS } & $1.037^{* *}$ & $1.042 * *$ & $1.108^{* *}, \mathrm{a}$ & $0.956 * *$ \\
\hline & $(0.031)$ & $(0.048)$ & $(0.042)$ & $(0.059)$ \\
\hline \multirow[t]{2}{*}{ OTHLNSLEAS } & $1.065^{* *}$ & $0.836 * *$ & $1.050^{* *}$ & $1.113^{* *}$ \\
\hline & $(0.092)$ & $(0.145)$ & $(0.114)$ & $(0.143)$ \\
\hline \multirow[t]{2}{*}{ OTHA1 } & $0.566^{* *}$, a & $0.754^{* *}$ & $0.530^{* *}$, a & $0.516^{*}, \mathrm{~b}$ \\
\hline & $(0.116)$ & $(0.180)$ & $(0.156)$ & $(0.225)$ \\
\hline \multirow[t]{2}{*}{ OTHA2 } & $1.154 * *$ & $0.918 * *$ & $1.182^{* *}$ & $1.038 * *$ \\
\hline & $(0.114)$ & $(0.186)$ & $(0.160)$ & $(0.194)$ \\
\hline \multirow[t]{2}{*}{ NPL } & $-1.427 * *$ & $-0.714^{*}$ & $-1.340 * *$ & $-3.012 * *$ \\
\hline & $(0.253)$ & $(0.290)$ & $(0.326)$ & $(0.575)$ \\
\hline \multirow[t]{2}{*}{ LLR } & 0.478 & -0.039 & -0.422 & 1.214 \\
\hline & $(0.617)$ & $(0.603)$ & $(0.658)$ & (0.849) \\
\hline \multirow[t]{2}{*}{ CORE } & $-0.903^{* *}, \mathrm{c}$ & $-0.915^{* *}, \mathrm{c}$ & $-0.915^{* *, \mathrm{c}}$ & $-0.819 * *, \mathrm{c}$ \\
\hline & $(0.016)$ & $(0.021)$ & $(0.027)$ & $(0.033)$ \\
\hline \multirow[t]{2}{*}{ OTHDEP } & $-1.035^{* *}$ & $-1.025^{* *}$ & $-1.055^{* *}$ & $-0.993 * *$ \\
\hline & $(0.018)$ & $(0.029)$ & $(0.030)$ & $(0.038)$ \\
\hline \multirow[t]{2}{*}{ OTHLIAB } & $-1.091^{* *, \mathrm{c}}$ & $-1.093^{* *, \mathrm{c}}$ & $-1.111^{* *, \mathrm{c}}$ & $-1.008^{* *}$ \\
\hline & $(0.023)$ & $(0.033)$ & $(0.031)$ & $(0.047)$ \\
\hline \multirow[t]{2}{*}{ FEE } & $2.650 * *$ & 1.133 & $3.255^{* *}$ & $3.071 * *$ \\
\hline & $(0.412)$ & $(0.614)$ & $(0.637)$ & $(0.726)$ \\
\hline \multirow[t]{2}{*}{ sdFEE } & -0.012 & 0.033 & -0.008 & -0.121 \\
\hline & $(0.022)$ & $(0.100)$ & $(0.029)$ & $(0.147)$ \\
\hline \multirow[t]{2}{*}{ FEE*sdFEE } & -0.971 & -0.258 & $-2.002 * *$ & 1.849 \\
\hline & $(0.556)$ & $(0.656)$ & $(0.592)$ & (1.797) \\
\hline \multirow[t]{2}{*}{ LASSETS } & $0.150^{* *}$ & 0.163 & -0.006 & -0.051 \\
\hline & $(0.029)$ & $(0.156)$ & $(0.241)$ & $(0.082)$ \\
\hline
\end{tabular}




$\begin{array}{lcccc}\text { OPEXP } & -2.370^{* *} & -1.658^{* *} & -2.652^{* *} & -3.811^{* *} \\ & (0.276) & (0.327) & (0.420) & (0.584) \\ \text { SHTRADAL } & -7.309^{* *} & 0.175 & -7.769^{* *} & -6.833^{*} \\ & (2.378) & (11.392) & (2.825) & (2.975) \\ \text { LHERF } & 0.062 & 0.072 & 0.023 & 0.094 \\ & (0.037) & (0.109) & (0.048) & (0.052) \\ \text { 1/BV } & -0.204 & -2.408 & -12.646 & -66.027^{*} \\ & (1.054) & (2.335) & (14.209) & (26.262) \\ \text { Constant } & -1.721^{* *} & -2.021 & 1.111 & 1.436 \\ & (0.598) & (2.384) & (3.433) & 742 \\ \text { Observations } & 2,596 & 763 & 1,091 & 0.9136 \\ \text { Adjusted R-squared } & 0.9137 & 0.9068 & 0.9353 & \end{array}$

Notes: Clustered (by BHC) standard errors are in parentheses. Each equation also includes RESV, SEC, FF, and TRADA, with coefficients constrained to one, and TRADL with its coefficient constrained to minus one. Each equation also contains a set of annual dummy variables, as well as a set of interactive variables consisting of GAP interacted with each of the annual dummy variables. ${ }^{* *}$ and $*$ indicate that a coefficient differs significantly from zero at the 1 percent and 5 percent levels, respectively. For asset categories, ${ }^{\mathrm{a}}$ and ${ }^{\mathrm{b}}$ indicate that a coefficient differs significantly from one at the 1 percent and 5 percent levels, respectively. For liability categories, ${ }^{\mathrm{C}}$ and ${ }^{\mathrm{d}}$ indicate that a coefficient differs significantly from minus one at the 1 percent and 5 percent levels, respectively. For small business loans, ${ }^{\mathrm{e}}$ and ${ }^{\mathrm{f}}$ indicate that the total effect of that small business loan category on MVBV differs significantly from one at the 1 percent and 5 percent levels, respectively.

Source: Y9-C, call reports 
Table 5: Determinants of market value of banking organizations with small business loans separated by size: full sample and by BHC size category

$\begin{array}{lcccc} & \text { All BHCs } & \begin{array}{c}\text { Assets below } 0.5 \\ \text { billion } \$ 2005\end{array} & \begin{array}{c}\text { Assets between } 0.5 \\ \text { and } 1.5 \text { billion } \$ 2005\end{array} & \begin{array}{c}\text { Assets above } 1.5 \\ \text { billion } \$ 2005\end{array} \\ \text { CI } & (1) & (2) & (3) & (4) \\ \text { SM1CI } & 0.944^{* *} & 0.897^{* *} & 0.993^{* *} & 0.915^{* *} \\ & (0.038) & (0.072) & (0.050) & (0.067) \\ \text { SM23CI } & 0.203 & 0.498^{* *}, \mathrm{f} & 0.165 & -0.369 \\ & (0.124) & (0.170) & (0.185) & (0.275) \\ \text { CRE } & 0.124 & 0.098 & 0.124 & 0.374 \\ & (0.068) & (0.111) & (0.110) & (0.191) \\ \text { SM1CRE } & 1.033^{* *} & 1.050^{* *} & 1.086^{* *} \mathrm{~b} & 0.900^{* *} \\ & (0.028) & (0.037) & (0.037) & (0.061) \\ \text { SM23CRE } & 0.271 & 0.227 & 0.256 & 0.252 \\ & (0.169) & (0.241) & (0.212) & (0.505) \\ \text { Observations } & -0.035 & -0.044 & -0.024 & 0.114 \\ \text { Adjusted R-squared } & (0.040) & (0.052) & (0.062) & (0.121) \\ & 2,596 & 763 & 1091 & 0.9150\end{array}$

Notes: Clustered (by BHC) standard errors are in parentheses. To save space, the table shows only a subset of the explanatory variables. However, each equation includes the same set of control variables as those in Table 4. ** and * indicate that a coefficient differs significantly from zero at the 1 percent and 5 percent levels, respectively. For asset categories, ${ }^{\mathrm{a}}$ and ${ }^{\mathrm{b}}$ indicate that a coefficient differs significantly from one at the 1 percent and 5 percent levels, respectively. For liability categories, ${ }^{\mathrm{c}}$ and ${ }^{\mathrm{d}}$ indicate that a coefficient differs significantly from minus one at the 1 percent and 5 percent levels, respectively. For small business loans, ${ }^{\mathrm{e}}$ and ${ }^{\mathrm{f}}$ indicate that the total effect of that small business loan category on MVBV differs significantly from one at the 1 percent and 5 percent levels, respectively.

Source: Y9-C, call reports 


\section{Appendix}

\section{Dependent Variable}

MVBV: The ratio of the bank's market value to its book value. The market value is constructed as the average of daily market values for the month of September. The bank's book value is its total equity capital minus its perpetual preferred stock and capital surplus using the June call reports.

\section{Loans and leases}

CI: Total commercial and industrial loans; measured as the bank's total commercial and industrial loans, divided by the book value of the bank.

CRE: Total commercial real estate loans; measured as the bank's total loans secured by nonfarm, nonresidential properties, divided by the book value of the bank.

CSTR: Total construction loans; measured as the bank's total construction, land development, and other land loans, divided by the book value of the bank.

RES: Total loans secured by 1-4-family residential properties; measured as the bank's total loans secured by 1-4-family residential properties, divided by the book value of the bank.

MULT: Total loans secured by multifamily residential properties; measured as the bank's total loans secured by multifamily residential properties, divided by the book value of the bank.

FARM: Total loans to farmers; measured as the sum of the bank's loans secured by farmland and loans to finance agricultural production and other loans to farmers, divided by the book value of the bank.

CCD: Total credit card loans; measured as the bank's credit card and other revolving plan loans, divided by the book value of the bank.

CONS: Total other consumer loans; measured as the bank's other consumer loans, divided by the book value of the bank.

OTHLNSLEAS: Total other loans and leases; measured as the sum of the bank's loans to depository institutions, loans to foreign governments, loans made by the bank's foreign offices, and all other loans and lease financing receivables, divided by the book value of the bank. 
Note, BHCs did not report their small business loans on a consolidated basis. Therefore, the small business loan series for BHCs were constructed by aggregating the small business loans held by the BHC's individual bank subsidiaries.

SMCI: Total small commercial and industrial loans; measured as the bank's total commercial and industrial loans with original amounts of $\$ 1$ million or less, divided by the book value of the bank.

SM1CI: Small commercial and industrial loans with original amounts of $\$ 100,000$ or less; measured as the bank's commercial and industrial loans with original amounts of $\$ 100,000$ or less, divided by the book value of the bank.

SM23CI: Small commercial and industrial loans with original amounts of more than $\$ 100,000$ through \$1 million; measured as the bank's commercial and industrial loans with original amounts of more than $\$ 100,000$ through $\$ 1$ million, divided by the book value of the bank.

SMCRE: Total small commercial real estate loans; measured as the bank's total real estate loans secured by nonfarm, nonresidential properties with original amounts of $\$ 1$ million or less, divided by the book value of the bank.

SM1CI: Small commercial real estate loans with original amounts of $\$ 100,000$ or less; measured as the bank's real estate loans secured by nonfarm, nonresidential properties with original amounts of $\$ 100,000$ or less, divided by the book value of the bank.

SM23CI: Small commercial real estate loans with original amounts of more than $\$ 100,000$ through \$1 million; measured as the bank's real estate loans secured by nonfarm, nonresidential properties with original amounts of more than $\$ 100,000$ through $\$ 1$ million, divided by the book value of the bank.

\section{Other balance sheet items}

SEC: Fair value of the bank' securities holdings; measured as the sum of the bank's securities held to maturity and available for sale securities, each measured at fair value, divided by the book value of the bank.

TRADA: Trading assets; measured as the bank's trading assets, divided by the book value of the bank.

RESV: Reserves; measured as the bank's cash and balances due from depository institutions, divided by the book value of the bank. 
FF: Net federal funds sold and securities purchased under agreements to resell; measured as the bank's federal funds sold and securities purchased under agreements to resell net of the bank's federal funds borrowed and securities sold under agreements to repurchase, divided by the book value of the bank.

OTHA1: Other assets - group 1; measured as the bank's other real estate owned, premises and fixed assets, goodwill and other intangible assets, divided by the book value of the bank.

OTHA2: Other assets - group 2; measured as the bank's unearned income on all types of loans, the bank's investments in unconsolidated subsidiaries and associated companies, customers' liability on acceptances outstanding, and other assets, divided by the book value of the bank.

NPL: Nonperforming loans; measured as the sum of the bank's loans over 90 days past due and nonaccruing loans, divided by the book value of the bank.

LLR: Loan loss reserves; measured as the bank's allowance for loan and lease losses, divided by the book value of the bank.

CORE: Core deposits; measured as the sum of the bank's demand deposits, NOW and other transaction accounts, money market deposit accounts and other savings accounts, divided by the book value of the bank.

OTHDEP: Other deposits; measured as the bank's time deposits, divided by the book value of the bank.

TRADL: Trading liabilities; measured as the bank's trading liabilities, divided by the book value of the bank.

OTHLIAB: Other liabilities; measured as the sum of the bank's other borrowed money, liability on acceptances executed and outstanding, subordinated notes and debentures, minority interest in consolidated subsidiaries, perpetual preferred stock and related surplus, and other liabilities, divided by the book value of the bank.

\section{Other control variables}

FEE: Fee income; measured as the bank's total noninterest income net of service charges on deposit accounts in domestic offices and net gains (losses) on sales of loans, leases and other real estate owned, divided by the book value of the bank.

sdFEE: Standard deviation of FEE; measured as annualized eight-quarter standard deviation of FEE scaled by the annualized eight-quarter mean of FEE 
LASSETS: Total real bank assets; measured as the logarithm of the bank's total assets deflated by the GDP deflator.

OPEXP: Noninterest (operating) expense; measured as the sum of the bank's expenses on salaries and employee benefits, expenses of premises and fixed assets, and other noninterest expense, divided by the total income of the bank (the sum of total interest income and total noninterest income).

SHTRADAL: Share of trading assets and liabilities in the total bank assets; measured as the sum of the bank's trading assets and trading liabilities, divided by the total assets of the bank.

LHERF: The logarithm of the Herfindahl index that measures the concentration of assets within a multibank holding company; constructed as follows:

$$
\text { LHERF }=\log \sum_{i=1}^{n}\left(\frac{100 * \text { Assets of Subsidiary }_{i}}{\text { Sum of Assets of All Subsidiaries }}\right)^{2}
$$

GAP: One year gap - a measure of interest rate risk exposure; measured as the bank's earning assets that are repriceable within one year or mature in one year, minus interest bearing deposit liabilities that reprice within one year or mature within one year, minus long-term debt that reprices within one year or matures within one year, divided by the book value of the bank. 